\title{
Teachers' perceptions of the coaching role in secondary vocational education
}

Citation for published version (APA):

Ketelaar, E., Den Brok, P., Beijaard, D., \& Boshuizen, E. (2012). Teachers' perceptions of the coaching role in secondary vocational education. Journal of Vocational Education \& Training, 64(3), 295-315.

https://doi.org/10.1080/13636820.2012.691534

DOI:

$10.1080 / 13636820.2012 .691534$

Document status and date:

Published: 01/01/2012

Document Version:

Other version

Document license:

CC BY-NC-ND

Please check the document version of this publication:

- A submitted manuscript is the version of the article upon submission and before peer-review. There can be important differences between the submitted version and the official published version of record. People interested in the research are advised to contact the author for the final version of the publication, or visit the DOI to the publisher's website.

- The final author version and the galley proof are versions of the publication after peer review.

- The final published version features the final layout of the paper including the volume, issue and page numbers.

Link to publication

\section{General rights}

Copyright and moral rights for the publications made accessible in the public portal are retained by the authors and/or other copyright owners and it is a condition of accessing publications that users recognise and abide by the legal requirements associated with these rights.

- Users may download and print one copy of any publication from the public portal for the purpose of private study or research.

- You may not further distribute the material or use it for any profit-making activity or commercial gain

- You may freely distribute the URL identifying the publication in the public portal.

If the publication is distributed under the terms of Article 25fa of the Dutch Copyright Act, indicated by the "Taverne" license above, please follow below link for the End User Agreement:

https://www.ou.nl/taverne-agreement

Take down policy

If you believe that this document breaches copyright please contact us at:

pure-support@ou.nl

providing details and we will investigate your claim.

Downloaded from https://research.ou.nl/ on date: 26 Apr. 2023 


\section{Teachers' perceptions of the coaching role in secondary vocational education}

Eveline Ketelaar, Perry den Brok, Douwe Beijaard \& Henny P. A. Boshuizen

\section{Citatie}

Ketelaar, E., den Brok, P., Beijaard, D., \& Boshuizen, H. P. A. (2012). Teachers' perceptions of the coaching role in secondary vocational education. Journal of Vocational Education \& Training, 64(3), 295-315.

\section{Keywords}

Teachers' coaching role . innovative secondary vocational education . teachers' perceptions 


\begin{abstract}
This article describes a study on teachers' perceptions of the coaching role in innovative secondary vocational education (SVE) in the Netherlands. Data from 109 teachers were collected by means of an online questionnaire, asking for their associations with the coaching role, goals concerning the coaching role, and typical coaching activities. Using multiple correspondence analyses, it was explored whether underlying dimensions could be found in teachers' perceptions of the coaching role. Relations between teachers' perceptions of the coaching role and background variables were also explored. The outcomes revealed that dominant themes in the teachers' perceptions were promoting and supporting students' meta-cognitive skills, creating a positive learning and working atmosphere, and guiding and actively supporting students. Two underlying dimensions regarding the perceptions of the coaching role could be detected. The extremities of these dimensions were interpretable in terms of learning environment and learning process on the one dimension, and general development and domain-specific development on the other. Teachers' background variables were not significantly related to their perceptions of the coaching role.
\end{abstract}




\section{Introduction}

A world in which technological developments and professional and social changes occur rapidly demands that people react to such changes and continue to develop themselves during their professional careers (Velde 1999; Vermunt and Verloop 1999). Such changes naturally have implications for education. Day $(2000,102)$ states that 'the changing world of the student, the impact of new technologies, and the changing demands of the world of work have implications for the kinds of teaching and learning that will go on in school.' In other words, these developments ask for vocational education that prepares students for work and life in such a rapidly changing world. The Dutch national government, in dialogue with the labour market, therefore decided that secondary vocational education (SVE) had to be innovated (Biemans et al. 2009). Central to this innovation is the shift from focusing on knowledge transmission to the facilitation of student learning. For teachers this meant that besides their role as a subject expert, they needed to take on a coaching role (Biemans et al. 2004; De Bruijn and Leeman 2011; Wesselink et al. 2007).

As the redesign of Dutch SVE is a top-down process regulated by the central government, teachers are expected to somehow make sense of what is being understood by it and, more specifically, by this coaching role. An educational innovation is not a fact, but is always subject to individual interpretation and sense-making. So, teachers confronted with an educational innovation make sense of it by interpreting what the demands and the consequences of the innovation are for themselves, in light of their own frame of reference about education and teaching (Luttenberg et al. 2009; Spillane, Reiser, and Reimer 2002). Although the need to move towards a more coaching role for teachers in the context of SVE seems to be acknowledged in vocational education, a clear picture of what this role should look like in practice is mostly lacking. Moreover, it is unclear how SVE teachers themselves perceive their coaching role. Therefore, the aim of this study is to explore these perceptions. The results of this study may contribute to the development of knowledge about the coaching role of teachers in SVE. Furthermore, it may lead to insights which can be used to support teachers who have to implement this new role, for example, in the design of training and courses about the coaching role.

\section{Innovative SVE in the Netherlands}

This study took place in the context of SVE in the Netherlands. In SVE students are prepared for starting their working career or for further studies in higher vocational education. SVE studies are often offered at so called regional educational centres, educating on average 7,500 students, within the following sectors: Care and Welfare, Business and Economics, and Technology. These sectors are subdivided into departments, offering a broad range of vocational trainings. Specific educational centres exist for the Agriculture sector; other vocational schools only offer programmes within one specific area, such as the graphical sector. The vocational trainings differ in duration (from 1 year up to 4 years), difficulty (from level 1 to level 4,1 with level 4 being the most difficult), and study-route (school-based: between $20 \%$ and $60 \%$ includes practical/workplace training and the remaining time is spent at school; work- 
based: at least $60 \%$ includes practical/workplace training and the remaining time is spent at school) (MBO Raad).

During the late 1990s, the Social-Economic Council and the Education Council advised the Dutch Government to revise the content and design of Dutch SVE. This advice was based on demands from the labour market, where it was noticed that professions and jobs were changing rapidly (Dutch Inspectorate of Education 2007). As a result, employees need to continue developing themselves, and react to developments and innovations in their work (Biemans et al. 2004; Biemans et al. 2009; Day 2000). Both councils expected that by redesigning SVE the gap between school and the labour market would be reduced and students would be better prepared for lifelong learning.

To be able to achieve the aforementioned goals, several core characteristics were formulated as a basis for redesigning SVE. Based on the work of De Bruijn and Leeman (2011), Koopman (2010), Van den Berg and De Bruijn. (2009), and Wesselink et al. (2007), these characteristics can be summarised as follows:

- Learning outcomes are conceptualised in terms of professional competencies, consisting of an integration of knowledge, skills and attitudes. Competencies needed in future working practice are taken as the starting point for curriculum development.

- Learning activities need to take place in workplaces and school contexts similar to the future occupational practice in which authentic or lifelike tasks are used.

- There is a focus on students' future professions and the competencies required to succeed, in order to elicit the development of their professional identity.

- Learning from authentic or lifelike tasks on which students' work is supported by offering required underlying knowledge and training of specific skills. Knowledge and skills are not only learned separately from practical situations, but students are stimulated to acquire and apply knowledge and skills in practical situations. This should lead to more coherence between theory and practice.

- Proven teaching methods (such as whole-class instruction) are related and brought into balance with more experimental practices (coaching students' learning processes). This also means that teachers have to become more flexible in their pedagogy, so that they can connect and cater to individual differences and needs amongst students.

- Students are challenged to develop meta-cognitive skills, such as self-regulation and self-reflection. They are made responsible for their own learning and they have to monitor their own development.

- Students are stimulated to learn cooperatively and to develop collaborative skills.

- Assessment and evaluation are directed at the development of (components of) students' competencies, their meta-cognitive skills, and their professional 
development and performance in authentic contexts.

Since 2004, several SVE schools have started to experiment with redesigning their learning environment and since August 2010, every SVE school was obliged to have started with the implementation of the new education (Dutch Inspectorate of Education 2007). However, De Bruijn and Leeman (2011) showed that the extent to which the above mentioned characteristics were implemented in Dutch SVE, differed considerably between schools and even within schools.

\section{The coaching role of teachers in innovative SVE}

The redesign of SVE asked for teachers to take on a more coaching role. This meant they had to focus more on students' career guidance, but also on coaching in the classroom. In career guidance, coaching is aimed at facilitating students in developing an individual learning and career path. This guidance often takes place in one-on-one career conversations, mostly outside the classroom (Mittendorff 2010). The present study, however, focuses on the teacher's coaching role in the classroom. This means that the guidance takes place in interaction with students who are working on tasks or projects related to competence development within their vocational domain. This interaction can take place when students are working individually or in cooperative groups, or in a whole-class situation. Classroom is in this case a broad concept, as in SVE schools classroom can refer to different rooms such as traditional classrooms, practical workplaces, and so called 'open study areas' with for example computers and tables for group work. The aim of the coaching role in the classroom is to support and guide students' learning processes, and in particular their self-regulated and independent learning (e.g. Bakker 2008; De Bruijn and Leeman 2011; Van Grinsven and Tillema 2006). This means that 'students are not left to their own devices, as the teacher is available to help them stay on the right track and reflect with them on their results and learning processes' (De Bruijn and Leeman 2011, 699). The teacher in the coaching role can therefore be seen as a facilitator of students' learning processes, anticipating the different (learning) needs of individual students (Iredale and Schoch 2010). In a literature study on career guidance, Meijers, Kuijpers, and Winters (2010) emphasize the importance of a good relationship between the teacher and the student. Several of the characteristics of a successful guidance relationship that they describe, might also apply to the coaching role in the classroom, such as frequent contact, a focus on the student's development, a strong input of the student which is stimulated by the teacher, offering structure and support, and feeling comfortable with each other (Meijers et al. 2010).

From the literature a broad range of teacher activities can be derived that seem related to the coaching role. Bakker (2008) distinguishes two typical overarching coaching interventions, namely giving feedback and asking questions. Both these coaching interventions can contain a range of more specific activities. Hattie and Timperley $(2007,81)$ define feedback as information provided by an agent (e.g. teacher, peer, book, parent, self, experience) regarding aspects of one's performance or understanding. [...] Feedback thus is a "consequence" of performance.' They state that feedback can be directed at four levels, namely the task level, process level, self-regulation level, and self level. Feedback directed at 
the task level is focused on how well students understand or perform the task, for example by giving marks. At the process level, feedback is used to inform students on the adequacy of the process they went through to complete the task or create a product, for example by giving them information on the strategies they use to make a calculation. Feedback at the self-regulation level addresses the ways students monitor, direct, and regulate their actions, for example by giving feedback on the way they plan their activities. Finally, feedback at the self level focuses on personal evaluations and affect about the student, containing hardly any task-related information, such as saying 'you're a good student.' Because of this lack of task-related information, feedback at the self level seems not to have much effect on a student's learning process (Hattie and Timperley 2007).

The second typical coaching intervention that Bakker (2008) distinguishes is asking questions. Questioning can activate students, for example by appealing to their prior subject knowledge (Bolhuis and Voeten 2001). Just like feedback, questions can also be of different order, such as surface questions and higherorder questions. Surface questions can enhance surface knowing and higherorder questions can enhance deeper understanding (Hattie 2009). Bolhuis and Voeten (2001) distinguish questions related to subject matter, questions related to the students' learning processes and general questions which are not related to subject matter or the learning process. This division is rather similar to the levels at which feedback can be directed, as proposed by Hattie and Timperley (2007). It seems therefore plausible to also apply these four levels to the coaching intervention of asking questions. That would result in questions at the task or content level (e.g. 'What is the capital of France?'), questions at the process level (e.g. 'How did you approach this task?'), questions at the selfregulation level (e.g. 'Looking back at how you approached and carried out this task, what would you do differently next time?') and questions at the self or personal level (e.g. 'How are you?').

Besides giving feedback and asking questions, additional coaching-related activities can be found in the literature (e.g. De Bruijn and Leeman 2011). A third category of typical coaching interventions can therefore be defined, which might be labelled as giving support. Concrete coaching activities in this regard are for example modelling (demonstrating how an act can or should be performed), thinking aloud (giving students insights into the thinking processes and strategies of an expert), providing help on demand (leaving the initiative with the student), providing adaptive instruction (providing necessary underlying subject knowledge), actively supporting (giving students extra support or extra challenges when needed) (De Bruijn and Leeman 2011), and paraphrasing (summarising what a student has said) (Scager and Thoolen 2006). 
Although a clear description of the coaching role in the context of (Dutch) innovative SVE has not yet been provided, several features may be derived from the above-mentioned theoretical framework. First of all, the students' learning processes are seen as the starting-points for the guidance. Second, the teacher is seen as facilitator of students' learning processes, by guiding, supporting and anticipating the different needs of students. A broad range of coaching interventions can be used, but these should especially be focused on improving students' self-regulated and independent learning. Moreover, an important condition for successfully bringing these coaching interventions into practice is a good relationship with the students.

\section{Research questions}

The aim of this study is to explore how SVE teachers themselves perceive the coaching role. To get more insight into similarities and differences in these perceptions, it can be useful to explore whether certain dimensions can be found within the underlying perception categories. Descriptions of such dimensions can be helpful in conceptualising complex and interrelated information, by representing the information in smaller and easier to understand chunks (Rickards, Den Brok, and Fisher 2005). If such dimensions exist in teachers' perceptions of the coaching role, it can be interesting to see whether teachers with different backgrounds and teaching contexts also have different perceptions of the coaching role. It might for example be the case that teachers teaching lower-level students have different perceptions about the coaching role than teachers teaching higher-level students. Or teachers might think that students who follow the work-based route and come to school only one day a week need a different approach than students who are at school several days a week. The following specific research questions were formulated to lead this study on SVE teachers' perceptions of the coaching role:

1 How do teachers in innovative SVE perceive the coaching role?

2 Which underlying dimensions can be found in teachers' perceptions of the coaching role?

3 What is the relation between teachers' perceptions of the coaching role and their background variables?

\section{Method}

An exploratory study was carried out to obtain insight into teachers' perceptions of the coaching role, possible underlying dimensions, and relations between teachers' perceptions and their background variables. A questionnaire was developed for this purpose, which was administered online. As there was not a clear prior concept of the coaching role and the aim of this study was to get a view on how teachers themselves perceive this role, the questionnaire contained mostly open-ended questions. By using an online questionnaire it was possible to obtain views of a fairly large number of SVE teachers in the Netherlands. 


\section{Respondents}

Teachers were asked to participate on a voluntary basis. Several strategies were used to recruit respondents for the questionnaire. Managers of different SVE institutions were contacted first. When they were willing to participate, they sent the request with a hyperlink to the questionnaire to the teachers of their teams and sometimes to managers of other departments. In addition, the network of a technical teacher training institute was used to contact alumni and SVE teachers directly and via the institute's website. An advantage of online administration is that it is easy to widely disseminate the questionnaire; however, non-response rate tracking is very difficult (Andrews, Nonnecke, and Preece 2003), as it is unclear how often the hyperlink to the questionnaire is forwarded or noticed at the website.

The questionnaire was completed by 109 teachers from 12 different SVE institutions. Ninety-seven respondents belonged to five of the 12 institutions (with a minimum of 11 and a maximum of 25 participating teachers per institution). From the other seven institutions, only one to four teachers per institution participated. The teachers had an average age of 46.6 years, ranging from 23 to 61 . Average experience as SVE teacher was 13.1 years, with a minimum of one year and a maximum of 34 years. By far most respondents were from the technology education sector (102), the remaining were teachers from the care and welfare sector (5) and the economics sector (2). As the technology education sector is dominated by male teachers, 90 participants were male, the other 19 were female. Furthermore, 78 respondents mostly taught students following the school-based route and 31 mostly taught students within the workbased route.

\section{Instrument}

A questionnaire on the teacher's coaching role was developed for the purpose of this study. Several stakeholders in the field of SVE (such as teacher trainers and SVE experts) were consulted to verify whether the topics included in the questionnaire were relevant to practice. The questionnaire was pre-tested with eight SVE teachers in order to check for comprehensibility and clarity of the questions. Only minor adjustments appeared to be necessary. The final questionnaire was digitalised and administered online.

Several personal background characteristics and information on teachers' profession were asked, namely gender, years of experience as a SVE teacher, their students' qualification levels, and their students' study-routes. Also a task was added to measure teachers' professional role conceptions. The teachers had to distribute 100 points over the following teacher roles: the teacher as a subject expert (bases his/her profession on subject matter knowledge and skills), a didactical expert (bases his/her profession on knowledge and skills regarding the planning, execution, and evaluation of teaching and learning processes), and a pedagogical expert (bases his/her profession on knowledge and skills to support students' social, emotional, and moral development). The amount of points that were ascribed to a certain role, determined the extent to which one recognised oneself in that role (cf. Beijaard, Verloop, and Vermunt 2000). 
An open-ended question was asked about the associations evoked when thinking about teacher's coaching role (cf. Wesselink, Biemans, and Mulder 2007). A minimum of one and a maximum of five associations could be entered.

Respondents were asked about what they thought were the most important goals concerning the coaching role in an open-ended question. A minimum of one and a maximum of three goals could be written down. For each goal, the respondents were asked to what extent the goal fitted their work as a teacher (on a five-point scale, ranging from 1 - hardly to 5 - very much).

To get insight into teachers' perceptions of typical coaching related activities, they were asked to choose from a list of 17 activities what they found were the most typical for the coaching role. These activities were mostly derived from literature (De Bruijn and Leeman 2011; Hattie and Timperley 2007; Scager and Thoolen 2006) and completed with information from exploratory classroom observations (executed by the first author). The 17 activities could be placed within the three categories of typical coaching interventions described above: giving feedback (containing five activities, for example 'giving feedback on the task level'), asking questions (containing five activities, for example 'asking questions on the process level') and giving support (containing seven activities, for example 'providing help on demand'). Each activity was explained briefly and an example was provided. Participants were asked, per category, to choose the two activities they found most typical for the coaching role and rank them (1 being most typical). Next, they were asked to pick the most typical activity for the coaching role across all three categories.

\section{Data analysis}

The data were analysed per research question. To answer the first research question, a separate category system was created for the two open-ended questions (associations and goals), following a similar procedure for both. The development of the category systems consisted of several steps.

1 Every association/goal was grouped with similar associations/goals.

2 Every group of associations/goals was given a label, using concepts derived

. from the literature underlying this study and from the data.

3 Groups of associations/goals overlapping too much were combined.

4 Every group of associations/goals was described as a category and illustrated with several examples. A separate category was ascribed to associations/goals that were incomprehensible or needed too much interpretation.

5 The final category system was used to categorise the data.

Part of the data was categorised by a second researcher. Interrater reliability (Cohen's Kappa) between two raters using the category systems for the associations was .81 (108 out of 380 associations) and for the goals .82 (107 out of 290 aims), indicating a satisfactory agreement between the two raters for both 
category systems. Associations, goals and activities were coded as missing values if an answer was lacking.

After categorising the answers to the open questions, descriptive statistics were carried out to answer the first research question. It included calculating frequencies and percentages of the associations, goals, and typical teacher activities.

To answer the second research question, a multiple correspondence analysis (MCA) was carried out. MCA is comparable to principal component analysis, but the variables to be analysed are categorical instead of quantitative (Abdi and Valentin 2007). The analysis results in a model with one or more dimensions. By interpreting the extremities of the dimensions, insights can be gained into the underlying structure that might exist in the data. In this case, MCA was used to discover how the categories of the associations, goals and activities were related to each other. That is, to find out which categories of these three variables often occurred together and which teachers had similar associations, goals, and teaching activities, or not.

For the use of MCA, it was necessary to start with some data reduction, as the respondents wrote down different numbers of associations (between one and five) and goals (between one and three). Therefore, for every respondent, only one association-category and one goal-category were included. The following rules were applied for selection of the overall association-category for each respondent (if more than one association was written down). If all associations belonged to different categories, the category to which the first association belonged was selected. If two or more associations belonged to the same category, that category was selected. If twice, two associations belonged to the same category, the 'first one written down' rule was applied to these four associations. The same approach was used to select the overall goal-category for each respondent. As outliers caused by low-frequency categories tend to distort the solution of MCA (Endedijk 2010), categories that were assigned only once to an association, a goal or an activity, were excluded from the MCA. Taken together, for each respondent, one association, one goal and three activities were included in the MCA.

To answer the third research question, teachers' mean scores on the dimensions of the MCA were compared with several background variables. The background variables included were gender, years of experience as a SVE teacher, their students' qualification levels, their students' study-routes and professional role conceptions. Years of experience was subdivided into three groups, namely early-career teachers (1-5 years; $33 \%$ of the respondents), mid-career teachers (6-19 years; $30.6 \%$ of the respondents), and late-career teachers (20+ years; $36.1 \%$ of the respondents). Students' qualification level was also subdivided into three groups, namely teachers mostly teaching students from the lowest levels (levels 1 and $2 ; 7.3 \%$ of the respondents), teachers mostly teaching students from the highest levels (levels 3 and 4; 37.6\% of the respondents), and teachers teaching students from both lowest and highest levels (55\% of the respondents). Independent samples t-tests were carried out for gender and students' studyroutes. One-way ANOVAs were carried out to compare the mean scores on the 
dimensions of the MCA with years of experience and students' qualification levels. For the professional role conceptions, correlations were calculated between the three roles and the dimensions of the MCA.

\section{Results}

Teachers' associations, goals, and typical teaching activities regarding the coaching role

\section{Associations with the coaching role}

In total, teachers reported 380 spontaneous associations with the coaching role. On average, each teacher reported 3.5 associations, with a minimum of one and a maximum of five. One teacher did not report any association. Fourteen categories could be detected within the data. The categories are presented in Table 1; they show the frequencies and percentages of associations within each category, and examples of associations for each category. By far the most associations were assigned to the category positive atmosphere, namely $16.7 \%$, followed by the category guidance and the category responsibility and reflection (both 10\%). The fewest associations were assigned to the category collaboration, only $1.3 \%$.

Table 1. Associations with the coaching role.

\begin{tabular}{|l|c|c|c|}
\hline Category & $\mathrm{N}$ & $\%$ & Examples of associations \\
\hline Positive atmosphere & 63 & $16.7 \%$ & Safe \\
\hline Guidance & & & $\begin{array}{c}\text { Pleasant contact with } \\
\text { students }\end{array}$ \\
\hline $\begin{array}{c}\text { Responsibility and } \\
\text { reflection }\end{array}$ & 38 & $10 \%$ & $\begin{array}{c}\text { Guide of the learning } \\
\text { process }\end{array}$ \\
\hline & $38 \%$ & $\begin{array}{c}\text { Let students work } \\
\text { independently }\end{array}$ \\
\hline Motivation and stimulation & 34 & $8.9 \%$ & Making students \\
& & & enthusiastic \\
\hline Help and support & 31 & $8.2 \%$ & Help students \\
\hline & & & Extra support for students \\
\hline
\end{tabular}




\begin{tabular}{|c|c|c|c|}
\hline $\begin{array}{l}\text { Cater to students' } \\
\text { individual needs }\end{array}$ & 29 & $7.6 \%$ & $\begin{array}{l}\text { Adapt method to student } \\
\text { needs }\end{array}$ \\
\hline & & & $\begin{array}{l}\text { Connect to students' world } \\
\text { of ideas }\end{array}$ \\
\hline \multirow[t]{2}{*}{$\begin{array}{l}\text { Monitoring learning } \\
\text { process }\end{array}$} & 27 & $7.1 \%$ & $\begin{array}{l}\text { Keep an eye on students' } \\
\text { progress }\end{array}$ \\
\hline & & & Planning \\
\hline \multirow[t]{2}{*}{ Negative utterance } & 26 & $6.8 \%$ & Inefficient \\
\hline & & & Time-consuming \\
\hline \multirow[t]{2}{*}{ Directing } & 22 & $5.8 \%$ & Directing a student \\
\hline & & & Signpost \\
\hline \multirow{2}{*}{ Subject expertise } & 13 & $3.4 \%$ & Knowledge transmission \\
\hline & & & $\begin{array}{l}\text { Discussing difficulties with } \\
\text { subject }\end{array}$ \\
\hline \multirow[t]{2}{*}{ (Lack of) structure } & 12 & $3.2 \%$ & Chaos \\
\hline & & & Be consistent \\
\hline \multirow[t]{2}{*}{ Positive utterance } & 12 & $3.2 \%$ & Fine \\
\hline & & & Important \\
\hline \multirow[t]{2}{*}{ Change and adaptation } & 11 & $2.9 \%$ & Different way of teaching \\
\hline & & & Innovative \\
\hline \multirow[t]{2}{*}{ Collaboration } & 5 & $1.3 \%$ & Stimulate collaboration \\
\hline & & & Teamwork \\
\hline (Incomprehensible) & (19) & $(5 \%)$ & -- \\
\hline Total & 380 & $100 \%$ & \\
\hline
\end{tabular}

\section{Goals with regard to the coaching role}

In total, teachers reported 290 goals. Two teachers did not report any goals. On average, each teacher reported 2.7 goals, with a minimum of one and a maximum of three. The goals teachers found most important concerning coaching in the classroom resulted in 10 categories (Table 2). Most goals were assigned to the category creation of a pleasant learning and working atmosphere (15.2\%), closely followed by promotion of self-regulation and independence and increasing student 
insight (both 14.8\%). Promotion of collaboration contained the fewest goals, only $3.4 \%$.

Table 2. Goals with regard to the coaching role.

\begin{tabular}{|c|c|c|c|}
\hline Category & $\mathbf{N}$ & $\%$ & Examples of goals \\
\hline \multirow{2}{*}{$\begin{array}{l}\text { Creation of a pleasant learning and } \\
\text { working atmosphere }\end{array}$} & 44 & $15.2 \%$ & Safe haven \\
\hline & & & Create peace in the classroom \\
\hline \multirow[t]{2}{*}{ Increasing student insight } & 43 & $14.8 \%$ & Learning to reflect \\
\hline & & & $\begin{array}{l}\text { Make students aware of their } \\
\text { learning process }\end{array}$ \\
\hline \multirow{2}{*}{$\begin{array}{l}\text { Promotion of self-regulation and } \\
\text { independence }\end{array}$} & 43 & $14.8 \%$ & Increasing independence \\
\hline & & & Self directedness \\
\hline \multirow[t]{2}{*}{ Guiding the learning process } & 35 & $12.1 \%$ & Guiding students \\
\hline & & & Support actively \\
\hline \multirow[t]{2}{*}{ Centralising individual student } & 30 & $10.3 \%$ & Student-directed \\
\hline & & & Connect to students' capacities \\
\hline \multirow{2}{*}{ Motivating and stimulating } & 28 & $9.7 \%$ & Stimulating students \\
\hline & & & Encouragement \\
\hline \multirow[t]{2}{*}{ F } & 19 & $6.6 \%$ & Graduate \\
\hline & & & $\begin{array}{l}\text { Everybody needs to reach the } \\
\text { finishing line }\end{array}$ \\
\hline \multirow[t]{2}{*}{$\begin{array}{l}\text { Knowledge and competence } \\
\text { development }\end{array}$} & 19 & $6.6 \%$ & $\begin{array}{l}\text { Let students acquire } \\
\text { knowledge }\end{array}$ \\
\hline & & & Grow in subject area \\
\hline \multirow[t]{2}{*}{ Learning-to-learn } & 18 & $6.2 \%$ & $\begin{array}{l}\text { Learning how to learn } \\
\text { something }\end{array}$ \\
\hline & & & $\begin{array}{l}\text { Teach students to learn } \\
\text { efficiently }\end{array}$ \\
\hline
\end{tabular}




\begin{tabular}{|l|l|l|l|}
\hline Promotion of collaboration & 10 & $3.4 \%$ & Let students collaborate \\
\hline & & & Promoting collaboration \\
\hline (Incomprehensible) & $11)$ & $(0.3 \%)$ & - \\
\hline Total & 290 & $100 \%$ & \\
\hline
\end{tabular}

Teachers believed that on average, the goals of the coaching role they mentioned themselves, fitted their work as a teacher very well, as the mean score of all categories together was 4.40 (SD $=.752$, minimum one and maximum five) and the mean scores per category were between 4.22 (learning-to-learn) and 4.53 (knowledge and competence development).

\section{Typical activities for the coaching role}

In Table 3 , the results with respect to typical activities for the coaching role are presented. Table $\underline{3}$ shows the frequencies and percentages of activities teachers found most typical and second most typical within each category, and the frequencies and percentages of activities teachers found most typical overall. 